\title{
ANÁLISE CRÍTICA DA EFETIVIDADE DO DIREITO HUMANO AO TRABALHO: UM IMPASSE NA DISCRIMINAÇÃO DE GÊNERO
}

\section{Ana Carla Harmatiuk Matos ${ }^{1}$ Samia Moda Cirino ${ }^{2}$}

"O corpo de uma mulher é um dos elementos essenciais da situação que ela ocupa neste mundo. Mas, não é ele tampouco que basta para a definir. Ele só tem realidade vivida enquanto assumido pela consciência através das açöes e no seio de uma sociedade" (Simone de Beauvoir).

\section{Resumo}

Com base em uma análise qualitativa, a partir dos dados empíricos apresentados nos Relatórios de Gênero elaborados pelo Instituto Brasileiro de Geografia e Estatística (IBGE), a Secretaria de Políticas para Mulheres (SPM) e a Organização Internacional do Trabalho (OIT), o artigo tem como objetivo demonstrar que a discriminação de gênero no trabalho ainda é uma realidade vivenciada pelas mulheres nas relações laborais, diante da dificuldade de inserção, permanência e ascensão no trabalho. Os resultados obtidos, a partir da análise dos relatórios de gênero e da revisão de literatura, evidenciam que essa circunstância decorre da construção social da identidade de gênero, mediante a reiteração de normas que regulam e produzem os diversos seres corporais, conforme uma lógica heterossexual e androcêntrica. Esse processo de formação da identidade social acaba por confirmar a divisão sexual do trabalho, que engendra as relações de exploração, dominação e opressão no trabalho produtivo e reprodutivo das mulheres. Ao final, a partir de uma leitura crítica das normas internas e dos tratados internacionais que regulamentam o trabalho da mulher, bem como de decisões judiciais que envolvem o trabalho delas, conclui-se pela necessidade de se adotar políticas de discriminação positiva e de se estabelecer um conceito de Direito Humano ao trabalho, conforme uma dimensão emancipatória, a fim de promover a igualdade de oportunidades e corrigir as diferenças materiais de gênero. Trata-se de pesquisa que se utilizou de instrumentos qualitativos, exploratórios e bibliográficos.

Palavras-Chave: Gênero. Direitos Humanos. Discriminação. Divisão sexual do trabalho. Trabalho da mulher.

\footnotetext{
${ }^{1}$ Professora na graduação, mestrado e doutorado em Direito da Universidade Federal do Paraná. Vice Coordenadora do Programa de Pós-graduação em Direito da Universidade Federal do Paraná. Professora de Direito Civil, de Direitos Humanos e de Novos Direitos. Diretora da Região Sul do IBDFAM.Vice-Presidente do IBDCivil. E-mail: a.c.matos@uol.com.br

${ }^{2}$ Doutoranda em Direito pela Universidade Federal do Paraná - UFPR, na linha de pesquisa de Direitos Humanos e Democracia. Mestre em Direito pela Universidade Estadual de Londrina-UEL na linha de pesquisa de Relações Empresariais. E-mail: samiamoda@hotmail.com
} 


\section{INTRODUÇÃO}

A análise das questões de gênero no trabalho, sob um enfoque formalista e meramente teórico, pode parecer um tema desatualizado e desatento aos ditos "avanços" obtidos na última década para o trabalho da mulher.

Propaga-se uma suposta igualdade de gênero tendo em vista as conquistas da igualdade meramente formal. E, mesmo as políticas adotadas para o alcance da igualdade material, partem, a nosso ver, de pressupostos equivocados acerca da construção da identidade de gênero e acabam por servir à lógica de normalização dos sujeitos, em relação ao papel do homem e da mulher na sociedade.

O objetivo é, no presente artigo, demonstrar que processos discriminatórios de gênero no trabalho ainda são uma prática vivenciada pelas mulheres brasileiras nas relações laborais, diante da dificuldade de inserção, permanência e ascensão no trabalho.

Os dados empíricos evidenciam esta desigualdade. Destarte, se analisadas as demandas judiciais e os relatórios de gênero no trabalho percebe-se que o propagado discurso de igualdade é deslocado da realidade vivenciada por milhares de mulheres. Discurso, aliás, que tão bem serve ao atual modelo de capitalismo, a fim de permitir a sua reprodução e mascarar a sua lógica de exploração e degradação do trabalho humano para o acúmulo incessante de capital.

A discriminação de gênero no trabalho, embora não seja uma inovação do capitalismo da contemporaneidade, é uma questão apropriada e agudizada no modelo de capitalismo que se pratica atualmente, pois aspectos como a precarização, a informalidade, a baixa remuneração, a dificuldade de acesso e permanência no mercado de trabalho, entre outros, são mais significativos no trabalho da mulher. Não se nega a importância de outros fatores, como classe e raça, para delinear as características do trabalho no atual capitalismo, contudo, esses fatores não podem ser isolados da questão de gênero, pois, conjuntamente, dão contornos específicos para a situação do trabalho da mulher.

A partir da análise dos relatórios do Instituto Brasileiro de Geografia e Estatística (IBGE), da Organização Internacional do Trabalho (OIT) e da Secretaria de Políticas para as Mulheres, bem como de recortes a partir de demandas judiciais e revisão bibliográfica, entende-se que a segmentação no mercado de trabalho é decorrente da construção social da identidade de gênero, vinculada a uma lógica androcêntrica e heterossexual. Esse processo de formação das identidades sociais acaba por confirmar a divisão sexual de ocupações, que engendra as relações de dominação, opressão e exploração do trabalho produtivo e reprodutivo da mulher.

Diante desse cenário, denuncia-se a construção da identidade de gênero como um processo natural, no intuito de demonstrar que a discriminação de gênero tem sua gênese na própria construção das identidades 
sociais. Longe de ser a expressão da vontade do sujeito, a identidade de gênero é performaticamente formada, ou seja, é compulsoriamente constituída a partir de um processo complexo de reiteração de normas que mascaram o conteúdo opressor dessa heteronormalização.

Ao final, a partir de uma leitura crítica das normas internas e dos tratados internacionais que regulamentam o trabalho da mulher, propõe-se a adoção de políticas de discriminação positiva, aptas a corrigir as desigualdades materiais de gênero. Ainda, propõe-se a ruptura com a atual concepção de Direito Humano do Trabalho, que confirma a divisão sexual do trabalho, para uma perspectiva emancipatória que permita a satisfação de necessidades e a construção da subjetividade/identidade do indivíduo para uma vida digna.

\section{DISCRIMINAÇÃO DE GENERO NO TRABALHO: UMA QUESTÃO SUPERADA?}

A precarização do trabalho humano e a desigualdade nas relações laborais do atual modelo de capitalismo flexível, conforme tese defendida por David Harvey ${ }^{3}$, tomaram tamanha proporção que, sob uma determinada análise, deslocada da realidade, poderia supor que no capitalismo da contemporaneidade tanto homens como mulheres tornam-se sujeitos de atividades passíveis de maior ou menor valorização.

De fato, a desvalorização do trabalho da mulher não é uma novidade do atual modelo de capitalismo. Contudo, a questão da discriminação de gênero é apropriada e agudizada pelo sistema capitalista, uma vez que as práticas laborais possibilitam a reprodução das práticas de gênero, onde a dominação, opressão e exploração do trabalho das mulheres atende ao escopo de expansão e acúmulo incessante de capital.

Assim, embora não se identifique no capitalismo a responsabilidade pela definição da forma como o gênero opera em nossa sociedade, certamente, o controle das sexualidades é utilizado por esse sistema para sua reprodução e consolidação. Afinal, uma análise empírica das relações de trabalho permite afirmar que a maior informalidade, baixa remuneração, dificuldade de acesso e permanecia no mercado de trabalho são características mais significativas na atividade laboral das mulheres.

O maior obstáculo para exercer cargos de chefia e de direção nos locais de trabalho se estende à estrutura sindical, sendo poucas as mulheres que exercem cargos de direção nos sindicatos e centrais sindicais, consoante observação feita por Paula Talita Cozero (2013, p. 240): "as próprias mediações da cultura patriarcal influenciam as opções de vida das mulheres no sentido de inibir seu autorreconhecimento como sujeito político, capaz de exercer cargos de poder".

Outrossim, não se nega a imbricada relação entre classe, raça e gênero, uma vez que a sociedade contemporânea é capitalista, racial e sexualmente dividida. As relações de classe e gênero são constitutivas uma da

\footnotetext{
${ }^{3}$ Sobre o capitalismo da contemporaneidade, adotamos a denominação capitalismo flexível, utilizada por David Harvey (2013, p. 148), para identificar as mudanças significativas implementadas no sistema de reprodução do capitalismo no final do século XX, estabelecendo um novo regime de acumulação e regulamentação do capital pautado no paradigma da flexiblidade.
} 
outra e se fundem em uma simbiose de lógica contraditória, conforme ressalta Heleieth Saffioti (1992, p. 206). Acerca da relevância das questões de gênero, referida autora complementa a ideia de "ser depropositada uma ciência que leve em conta apenas a contradição entre as classes sociais, deixando de lado o antagonismo entre gêneros ou vice-versa" (1992, p. 206). Destarte, a consciência de classe toma outros contornos quando se questiona acerca das oposições contraditórias vividas no seio da mesma classe social, ou seja, da heterogeneidade deste agrupamento social. Consoante ensina Heleieth Saffioti (1992, p. 207), os interesses de gênero tornam fragmentada a consciência de classe.

Por isso, uma adequada análise sobre a questão da discriminação do trabalho da mulher deve observar o processo histórico de construção do Direito do Trabalho, a fim de desvelar alguns mitos que o constituíram. De fato, não causa especial estranheza a negação de discriminação de gênero no trabalho, ao se considerar que uma parcela expressiva da doutrina ainda acredita e defende que o Direito do Trabalho, especialmente o brasileiro, é altamente protetivo ao trabalhador. Olvida-se analisar os mecanismos de legitimação e reprodução do sistema capitalista. Principalmente, não se verifica o contexto em que surgiu e se desenvolveu o Direito do Trabalho no Brasil.

Isso porque se acredita que toda a análise em torno da relação de emprego deve considerar que sua regulamentação ocorreu por meio do que se pode chamar de Direito Capitalista do Trabalho, pois buscou como objetivo final (ainda que menos aparente) satisfazer os interesses dos capitalistas de duas maneiras, conforme ressalta Wilson Ramos Filho (2013, p. 94): melhorar as condições de trabalho dos empregados, a fim de aprimorar a exploração de sua força de trabalho, elevando a extração da mais-valia e, ainda, diminuir as tensões e os conflitos decorrentes das condições históricas.

Mesmo com tais observações não se nega a importância da luta de classes para o reconhecimento de direitos mínimos aos trabalhadores, contudo mostra-se necessária a análise histórica do Direito do Trabalho, a qual evidencia que esse ramo do Direito foi estabelecido nitidamente em prol dos interesses dos detentores do capital. Assim, as contrapartidas ofertadas aos trabalhadores buscaram, na verdade, conformar essa classe ao modo de vida capitalista, mascarando os conflitos de classe, a fim de se consolidar como sistema econômico e social hegemônico.

No Brasil, a situação dos trabalhadores é ainda mais crítica, uma vez que não tivemos a efetividade das contrapartidas sociais características do Estado de Bem-Estar. Se nos países de capitalismo central as reformas visando à diminuição de direitos trabalhistas foram implementadas, de forma mais significativa, a partir dos anos 1980, sob a égide do neoliberalismo, no Brasil, essa quebra de rigidez do Direito do Trabalho ocorreu antecipadamente, durante o regime militar. Esse cenário nacional explica o hibridismo constitucional de 1988, que sintetizou enunciados da disputa entre as propostas de contraprestação aos trabalhadores e as propostas de (re) 
regulamentação e precarização das relações de trabalho".

Nesse contexto, a desvalorização do trabalho da mulher serve aos propósitos do capitalismo, pois as relações de gênero exercem um papel importante na estratificação do mercado de trabalho. Por isso, o estudo desta discriminação não significa dedicar-se a uma pesquisa pontual, de uma categoria de mão de obra singular, colocada à parte-as mulheres. Conforme ressalta Freire (2010, p.11), trata-se de uma análise do desenvolvimento da colocação de homens e mulheres no mercado de trabalho, capaz de identificar as mudanças estruturais no sistema de produção capitalista, que produziram as transformações da população ativa.

A discriminação do trabalho feminino, consoante explica Thereza Cristina Gosdal (2006, p. 305), apresenta "a peculiaridade de sobrepujar as mudanças econômicas e de se reinventar sob o capitalismo, fundada nas diferentes capacidades sexual e afetiva reconhecidas a homens e mulheres, a partir do imaginário social". A divisão sexual do trabalho na sociedade capitalista da contemporaneidade, principalmente após a reestruturação produtiva do capitalismo ${ }^{5}$, que dá ensejo à discriminação no trabalho, é evidenciada na maior precarização e desvalorização das atividades laborais essencialmente femininas, permitindo novas formas de assédio, segmentação e discriminação nas relações de trabalho.

Tal circunstância é corroborada pelos relatórios elaborados por instituições que cuidam da questão de gênero no trabalho. É pertinente ressaltar que, não obstante os dados apresentarem um panorama geral, portanto, não coincidente com todas as atividades laborais, são importantes parâmetros para a análise da situação do trabalho das mulheres na nossa sociedade. Isso porque, como são elaborados a partir de critérios objetivos (escolaridade, cargo, remuneração, jornada, tempo de serviço etc.), permitem identificar um certo padrão de conduta em relação ao trabalho feminino. Consoante ressalta Aldacy Rachid Coutinho (2000, p. 19), embora, em geral, a discriminação de gênero "não se apresente em uma mesma ocupação e estabelecimento, sempre vem acompanhada de uma segregação no interior do local de trabalho com condições gerais de trabalho (direitos, percentuais remuneratórios) inferiores".

Nesse sentido, uma pesquisa realizada pela Secretaria de Políticas para Mulheres em 2014 (publicada em 2015), de acordo com os últimos indicadores censitários (de 2010) do Sistema Nacional de Informações de

\footnotetext{
${ }^{4}$ Sobre a regressão no Direito do Trabalho Brasileiro durante o regime militar destacam-se as considerações de Wilson Ramos Filho (2012, p. 275): "[...] controlou-se rigidamente o Poder Normativo, seja o negocial pela intervenção nos sindicatos, seja o da Justiça do Trabalho; extinguiu-se a estabilidade no emprego e o sistema de indenização por tempo de serviço e, ignorando o comando fordista de melhoria das condições de remuneração, promoveu-se a transferência de renda da classe trabalhadora ao empresariado. [...]. Enquanto o capitalismo sofria a crítica anticapitalista nos EUA e na Europa no final dos anos 60, no Brasil se assistia ao endurecimento do regime, à edição do AI-5 e ao recrudescimento da repressão que encarcerou milhares de ativistas políticos e assassinou centenas de trabalhadores, tendo por fundamentação a defesa dos direitos humanos e a defesa do capitalismo contra aqueles agentes subversivos que queriam implantar o comunismo no Brasil".

${ }^{5} \mathrm{Ou}$ seja, mudanças nos modelos organizacionais, nos modelos de gestão do trabalho e da produção como um todo, graças aos avanços tecnológicos, em face da crise vivenciada pelo modelo fordista-taylorista anterior à década de 1980. Caracteriza-se por um novo modelo organizacional que busca a eficiência por intermédio da flexibilidade e precarização das relações laborais, em empresas esbeltas, organizadas em rede.
} 
Gênero do Programa de Estatísticas de Gênero no IBGE, evidencia a desvalorização do trabalho feminino, pois, embora, em geral, apresentem maior nível de escolaridade em relação aos homens, percebem remuneração inferior, principalmente por estarem concentradas em atividades menos valorizadas. Os índices demonstram que a diferença remuneratória também ocorre quando são consideradas as mesmas áreas de trabalho.

De acordo com a referida pesquisa, em 2012, havia um contingente maior de mulheres entre os universitários de 18 a 24 anos de idade, representando 57,2\% do total de estudantes que frequentavam o ensino superior e $61,2 \%$ dos concluintes dos cursos de graduação $(2015, \text { p. } 24)^{6}$.

Ainda, identificou-se que as áreas gerais de formação, nas quais as mulheres, com 25 anos ou mais de idade, estão em maior proporção, são as consideradas tipicamente femininas. Assim, identifica-se a divisão sexual do trabalho, associada a tarefas de cuidado e de reprodução, como as áreas de educação e da saúde.

De acordo com o Relatório Anual Socioeconômico da Mulher de 2014 (publicado em março de 2015), houve, em 2012, grande concentração de mulheres nos cursos das áreas de Desenvolvimento Social e Educacional; Ambiente e Saúde; Turismo, Hospitalidade e Lazer; Produção Cultural e Design; e, Produção Alimentícia $\left(2015\right.$, p. 24) ${ }^{7}$. Essas áreas são reconhecidas como tipicamente femininas e apresentam menor rendimento mensal médio entre as pessoas ocupadas, conforme pesquisa publicada em 2014 pelo IBGE a partir da análise dos indicadores do último Censo Demográfico de 2010. Contudo, o diferencial remuneratório se mantém mesmo quando a proporção de mulheres se torna equivalente à dos homens em outras áreas, como "Ciências Sociais, Negócios e Direito", nas quais as mulheres recebiam 66,3\% do rendimento dos homens.

Assim, mesmo escolarizadas, a remuneração do trabalho das mulheres ainda é menor em comparação aos vencimentos dos homens. De acordo com o Relatório Anual Socioeconômico da Mulher (de 2014)9 , em 2012, de forma geral, as mulheres apresentavam um rendimento-hora do trabalho principal equivalente a $\mathrm{R} \$ 10,2$ (dez reais e vinte centavos), enquanto os homens, no geral, recebiam o equivalente a $\mathrm{R} \$ 12,2$ (doze reais e vinte centavos) (2015, p. 55). A discrepância é ainda maior se considerarmos os rendimentos de um homem branco em relação às mulheres negras ${ }^{10}$. Note-se que, em 2012, enquanto uma mulher branca recebia por hora de trabalho, no geral, o montante de R\$ 12,5 (doze reais e cinquenta centavos) e um homem branco, no geral, recebia o equivalente a $\mathrm{R} \$ 15,6$ (quinze reais e sessenta centavos), as mulheres negras recebiam, no geral, $\mathrm{R} \$ 7,7$ (sete reais e setenta centavos) (2015, p. 90).

\footnotetext{
${ }^{6}$ Relatório disponível em http://www.spm.gov.br/central-de-conteudos/publicacoes/publicacoes/2015/livroraseam_completo.pdf

${ }^{7}$ Ibidem

${ }^{8}$ Dados disponíveis em http://biblioteca.ibge.gov.br/visualizacao/livros/liv88941.pdf

${ }^{9}$ Relatório disponível em http://www.spm.gov.br/central-de-conteudos/publicacoes/publicacoes/2015/livroraseam_completo.pdf vol.09, no. 04, Rio de Janeiro, 2016.pp. 1955-1981 
Igualmente, a diferença dos rendimentos por gênero também é agravada se considerarmos os anos de estudo. Enquanto as mulheres, em 2012, no geral, receberam o equivalente a R\$ 19,6 (dezenove reais e sessenta centavos) por hora de trabalho para 12 anos de estudos ou mais, os homens, no geral, receberam para o mesmo tempo de estudo R $\$ 29,6$ (vinte e nove reais e sessenta centavos) $(2015, \text { p.90) })^{11}$.

Seguindo essa linha de raciocínio, os indicadores sobre a concessão de bolsas de formação e fomento à pesquisa do Conselho Nacional de Desenvolvimento Científico e Tecnológico ( $\mathrm{CNPq}$ ) também parecem importantes para demonstrar o viés sexista. Conforme o padrão do número de matrículas no ensino superior, em 2012, as mulheres tinham importante representação no acesso a bolsas de pesquisa nos níveis iniciais de sua formação acadêmica (56,5\% das bolsas de iniciação científica), mas sua participação se reduz nos níveis superiores, com 50,6\% das bolsas de doutorado, além de serem minoria entre os bolsistas no exterior $(45,1 \%)$ $(2015, \text { p. 26) })^{12}$.

Já no nível mais alto, o CNPq atribui a Bolsa de Produtividade Sênior a 26 pesquisadores que se destacam como líderes em sua área de atuação, sendo que as mulheres representavam somente 21,6\% destes bolsistas. Esses dados parecem demonstrar, entre outros, a dificuldade de acesso das mulheres a posições de poder e a cargos de liderança no mercado de trabalho - tendo em vista que as Bolsas de Produtividade evidenciam parte da estrutura de poder das universidades e centros de pesquisa do país ${ }^{13}$ (2015, p. 26).

Do mesmo modo, a taxa de desocupação entre as mulheres, de acordo com o Relatório Anual Socioeconômico da Mulher - RASEAM, de 2014, foi quase 80\% superior à masculina, com importantes disparidades regionais e por grupos de idade. Além disso, a população mais vulnerável foi a de jovens entre 16 e 24 anos. Ainda, identificou-se que a proporção de mulheres em trabalhos formais foi pouco inferior à de homens, entretanto houve significativas diferenças de acordo com a raça ou cor: somente $48,4 \%$ das mulheres negras estavam em trabalhos formais, frente a $64,6 \%$ dos homens brancos $(2015, \text { p. } 16)^{14}$.

Igualmente, de acordo com o Relatório da Organização Internacional do Trabalho (OIT), de 2011, com a crise mundial de 2008, houve um aumento na discriminação no trabalho, principalmente das mulheres e dos estrangeiros. "Com os salários das mulheres correspondendo apenas a 70 a $90 \%$ dos homens para trabalho de igual valor, a não discriminação na remuneração deve ser um elemento essencial das medidas tanto para atingir a

\footnotetext{
${ }^{10}$ Imperioso ressaltar que, uma adequada análise das relações de gênero não pode negligenciar a articulação das relações de raça, de sexo, de classe e de sexualidade, uma vez que todos esses fatores, conjuntamente, influenciam as formas dominantes de arranjos entre os sexos e os estereótipos de gênero.

${ }^{11}$ Relatório disponível em http://www.spm.gov.br/central-de-conteudos/publicacoes/publicacoes/2015/livroraseam_completo.pdf

${ }^{12}$ Ibidem

${ }^{13}$ Ibidem

${ }^{14}$ Ibidem
} 
igualdade de gênero como a redução da pobreza" ${ }^{15}$.

Destarte, as taxas de desemprego mostram que os negros e as mulheres são dispensados em maior proporção nos momentos de crise e que também são os primeiros a serem afetados pela perda do emprego. Em 2006 a taxa total de desemprego das pessoas acima de 16 anos foi de 8,4\%. Entre os negros o desemprego foi de $9,4 \%$ e entre brancos de $7,4 \%$. Entre as mulheres foi de $11 \%$ e entre os homens de $6,3 \%$. Isso demonstra o peso relevante da dimensão de gênero sobre a oportunidade de acesso e de manutenção dos postos de trabalho - e o peso negativo que recai sobre as mulheres (MARQUES; SANCHES, 2010, p. 61).

Ainda, em 2015, à medida que a recessão econômica passou a afetar diretamente o mercado de trabalho nacional, aumentaram a taxa de desemprego e a porcentagem de ocupações informais, com decréscimo do rendimento médio dos trabalhadores. Mas, essa conjuntura desfavorável não ocorre de forma homogênea, uma vez que afeta os trabalhadores mais vulneráveis do ponto de vista ocupacional, ou seja, aqueles que exercem os trabalhos mais precários, dentre os quais, se insere de modo especial o trabalho da mulher.

Portanto, vários indicadores mostram que existe uma segmentação no mercado de trabalho em face, entre outros, da divisão sexual de ocupações, da inferior valorização social, da maior precariedade e informalidade, bem como de postos de menor hierarquia dentro de cada ocupação, com menores salários, prestígio e poder de decisão.

\section{A CONSTRUÇÃO SOCIAL DA IDENTIDADE DE GENERO}

O presente trabalho aborda a questão da identidade de gênero conforme uma perspectiva dinâmica e emancipatória, que varia entre as diversas culturas e classes. Assim, de acordo com as condições sócio-históricas, apresentam-se diversas formas como os indivíduos interpretam, assimilam e encarnam os papéis masculinos e femininos, ou outra construção de gênero, em uma sociedade.

Acredita-se que a questão da construção da identidade de gênero não deve ser ingenuamente abordada como uma decorrência natural da espécie humana, pois é, equivocadamente, determinada na organização social de acordo com as relações de poder estabelecidas entre homens e mulheres e dentre elas, encontra-se também a divisão sexual do trabalho. Consoante ensina Aldacy Rachid Coutinho (2000, p. 15), o gênero representa as relações de poder em que a exploração e o domínio masculino, opressor, é apresentado como natural e inquestionável.

O discurso da naturalidade do gênero faz com que as atividades femininas sejam entendidas como derivações biológicas e não como formulações socioculturais, historicamente forjadas. "A desigualdade entre os

\footnotetext{
${ }^{15}$ Relatório da OIT sobre igualdade no trabalho, 2011, p.25, disponível em: http://www.oitbrasil.org.br/sites/default/files/topic/discrimination/pub/igualdade\%20no\%20trabalho_relatorio\%202011_707 .pdf
} vol.09, no. 04, Rio de Janeiro, 2016.pp. 1955-1981 
sexos é vista como uma condição natural necessária, não como um produto da cultura e da sociedade, que pode ser modificado" (GOSDAL, 2006, p. 306).

Uma vez que, na nossa sociedade, a construção da identidade de gênero é entendida como um processo natural e como uma imposição cultural, pode-se afirmar que a discriminação de gênero tem origem na própria construção social das identidades, que "é sexuada e contextualizada em uma inter-relação com a raça e a classe social, em um espaço de dominação cultural 'androcêntrica e eurocêntrica' que determina os parâmetros da edificação das desigualdades" (COUTINHO, 2000, p. 13). De fato, a divisão sexual das tarefas não é representativa da capacidade física e intelectual das mulheres, pois é estabelecida, arbitrariamente, conforme uma imagem social da condição humana (COUTINHO, 2000, p. 13).

Assim, o gênero é utilizado para estabelecer na sociedade a separação entre o trabalho produtivo e remunerado, tradicionalmente reconhecido como "funções masculinas", e o trabalho doméstico e reprodutivo, em regra, visualizado como "atividades tipicamente femininas". Nesse viés sexista, "as mulheres são responsáveis pelo trabalho meramente reprodutivo, de âmbito doméstico, ligado diretamente à conservação da estrutura familiar, e desvalorado em uma sociedade de mercado que preza o valor de troca" (COUTINHO, 2000, p. 14). Por outro lado, os homens ocupam um lugar de primazia na divisão social do trabalho, uma vez que a eles são destinadas as atividades intelectuais ou de capital intensivo. Às mulheres restam, prioritariamente, as atividades rotinizadas, de menor qualificação, remuneração e prestígio social, gerando formas de exploração, dominação e opressão tipicamente sexista.

Dessa forma, ainda que tenham níveis de habilidades e escolaridade semelhantes, ou até mesmo superiores, as mulheres exercem, em sua maioria, atividades produtivas socialmente menos valorizadas. Há uma tendência de se atribuir um status social secundário às atividades produtivas e reprodutivas das mulheres. "Este padrão é projetado para o mundo do trabalho, onde as profissões feminizadas, que guardam alguma similitude com as tarefas domésticas e com o papel da mulher na família, como enfermeiras, professoras e secretárias, são socialmente desvalorizadas e mal remuneradas" (GOSDAL, 2006, p. 307).

Verifica-se que a questão da identidade de gênero, que importa para o tema em debate, envolve dois aspectos centrais: a fixação do gênero como uma condição natural, decorrente de aspectos biológicos, que confunde gênero e sexo; e a imposição do gênero como um constructo cultural, a fim de mascarar relações de $\operatorname{poder}^{16}$.

\footnotetext{
${ }^{16} \mathrm{~A}$ discussão, portanto, deve ser deslocada para a questão identitária, sem cair no reducionismo de uma análise apenas sobre a realização de um papel social. Trata-se de analisar e desvelar o processo de formação da identidade e subjetividade do sujeito no que tange à sua sexualidade, seu corpo, seu sexo, suas práticas sexuais. A afirmação de que a discriminação de gênero decorre do fato de as formas humanas se organizarem e obedecerem a regras comuns quanto ao papel do homem e da mulher, o que explicaria um padrão similar também em organizações sociais não ocidentais, é, a nosso ver, por demais simplista, passando por alto da complexidade do processo que envolve a constituição do gênero. $O$ problema, portanto, vai muito além e se insere no vício do nosso olhar sobre o Outro, na ocultação acerca da performatividade do gênero, ou seja, da internalização das normas que se vol.09, no. 04, Rio de Janeiro, 2016. pp. 1955-1981 1963
} 
Essas premissas precisam ser desconstruídas para a subversão da identidade de gênero conforme uma perspectiva emancipatória. Por isso sempre atual revisitar a tese exposta por Simone de Beauvoir na obra $O$ Segundo Sexo, da qual se extrai a célebre frase "Não se nasce mulher, torna-se mulher" (BEAUVOIR, 2009, p. 361). Essa afirmação contém a nítida a distinção entre sexo e gênero, além de sugerir que gênero é um aspecto da identidade gradualmente adquirido. A tese defendida por Beauvoir refere-se ao sexo não apenas como um fato biológico, mas enquanto sexo vivido de forma cultural, convergindo, no final da obra, para a superação do papel socialmente imposto à mulher, na busca da transcendência e autorrealização.

Em Judith Butler, na obra Problemas de Gênero: feminismo e a subversão da identidade, o gênero é um constructo social que, normalmente, oculta sua gênese e seu caráter performativo ${ }^{17}$. Esta autora questiona o sexo como um dado natural e o gênero como um dado determinado culturalmente. Ela busca desconstruir as categorias pré-discursivas, que pré-determinam os sujeitos, afirmando a indeterminação e a instabilidade da identidade de gênero por envolver um processo contínuo e dinâmico. Nesse sentido, para ela, gênero não é algo que somos, mas algo que fazemos a partir das normas e possibilidades culturais que nos são abertas ${ }^{18}$.

Tal pensamento abre a percepção de que o acordo coletivo tácito de produzir, exercer e sustentar gêneros distintos, como ficções culturais e conforme uma lógica binária e heterossexual, é acobertado pela credibilidade dessas produções, bem como pelas punições àqueles que se opõem a essas normas. "As possibilidades históricas materializadas por meio dos vários estilos corporais nada mais são do que ficções culturais punitivamente reguladas, alternadamente incorporadas e desviadas sob coação" (BUTLER, 2015, p. 241).

Dessa forma, Judith Butler (2015, p. 76) adverte que, localizar o mecanismo mediante o qual o sexo se transforma em gênero, permite estabelecer não só o caráter não natural e não necessário da construção do gênero, mas também a universalidade cultural da opressão das mulheres.

materializam no corpo e criam um efeito de substância do eucom gênero constante.

${ }^{17} \mathrm{O}$ conceito de performatividade é central para a tese de Judith Butler. Considerar o gênero como performativo significa que ele é ficticiamente construído por meio de "práticas regulatórias e de repetição que impõem uniformidade no comportamento estabelecido como coerente pela cultura no que diz respeito a sexo e gênero" (REIS, 2013, p.365). Assim, a performatividade do gênero é caracterizada pela reprodução reiterada de modos de agir, que impõem os comportamentos femininos e masculinos na sociedade.

${ }^{18} \mathrm{~A}$ fim de se estabelecer uma coerência discursiva, cumpre ressaltar que, não obstante abordagem adotada no presente estudo, no aspecto geral, marxiana, a referência ao pensamento de Simone de Beauvoir, de abordagem existencialista, e aos estudos de Judith Butler, de base pós-estruturalista, visou a criticar a construção da identidade de gênero como um processo natural. O intuito, portanto, é pensar as formas através das quais somos constituídos por meio de práticas de exercício de poder (disciplinadoras e normalizadoras) e de discursos sociais que incidem sobre nós para a construção das identidades sociais. Outrossim, embora a tematização do gênero a partir da divisão sexual do trabalho não seja uma abordagem típica de Judith Butler, consideramos que a construção social da identidade de gênero, descrita nos seus estudos, confirma a divisão sexual do trabalho, fomentando e reproduzindo essa lógica, pois se trata de elemento central de diferenciação das práticas humanas (dentre as quais se inserem as práticas laborais). 
A distinção entre sexo e gênero, assim, tem sido crucial para o esforço de desmascarar a alegação de que anatomia é destino. "Não é a natureza que define a mulher: esta é que se define retomando a natureza em sua afetividade" (BEAUVOIR, 2009, p. 71). Uma vez que o gênero não decorre de um processo natural entre sexo e identidade sexual, torna-se incoerente atribuir valor ou funções sociais à mulher de acordo com necessidades biológicas, conforme normas performartivas e naturalizantes. Sobre o papel da constituição biológica na construção do gênero, são relevantes os esclarecimentos de Simone de Beauvoir (2009, p. 65):

Esses dados biológicos são de extrema importância: desempenham na história da mulher um papel de primeiro plano, são um elementos essencial de sua situação. [...] Pois, sendo o corpo o instrumento de nosso domínio no mundo, este se apresenta de modo inteiramente diferente segundo seja apreendido de uma maneira ou de outra. Eis porque os estudamos tão demoradamente; são chaves que permitem compreender a mulher. Mas o que recusamos é a ideia de que constituem um destino imutável para ela. Não bastam para definir uma hierarquia dos sexos; não explicam por que a mulher é o Outro; não a condenam a conservar para sempre essa condição subordinada.

Nessa perspectiva, ser de um determinado sexo não é uma causa necessária para se tornar um determinado gênero. Conforme explica Judith Butler (1986, p. 35), a distinção entre sexo e gênero implica a radical heteronomia de corpo natural e gênero construído, com a consequência de que ser fêmea e ser mulher são dois diferentes tipos de existência.

Além disso, a identidade de gênero não pode ser entendida como uma determinação estática, construída passivamente por um sistema personificado de linguagem androcêntrica, que precede e determina o próprio sujeito. Esse modelo paternalista exploratório de aculturação, consoante ressalta Judith Butler (1986, p. 41), que trata os seres humanos apenas como produtos de causas anteriores, culturalmente determinados, não deixa espaço para possibilidades de transformações pessoais. O gênero não é apenas um constructo cultural imposto à identidade, mas, também, um processo de autoconstrução.

Embora sejam inegáveis as imposições sociais, o gênero envolve um processo contínuo de construção da identidade por meio da interpretação e ressignificação dessas normas sociais e do seu próprio corpo pelo sujeito. Nesse sentido, ensina Judith Butler (2015, p. 69):

Se há algo de certo na afirmação de Beauvoir, de que ninguém nasce e sim torna-se mulher, decorre que mulher é um termo em processo, um devir, um construir de que não se pode dizer com acerto que tenha uma origem ou um fim. Como uma prática discursiva contínua, o termo está aberto a intervenções e ressignificações. Para Beauvoir, nunca se pode tornar-se mulher em definitivo, como se houvesse um telos a governar o processo de aculturação e construção. $O$ gênero é a estilização repetida do corpo, um conjunto de atos repetidos no interior de uma estrutura reguladora altamente rígida, a qual se cristaliza no tempo para produzir a aparência de uma substância, de uma classe natural de ser.

Para ser um gênero, seja homem, mulher, ou outro, é preciso, conforme esta autora, estar engajado em várias interpretações culturais sobre o corpo e estar dinamicamente posicionado entre várias possibilidades culturais. Ou seja, a construção da identidade de gênero envolve um processo dinâmico de interpretação do corpo, dando a ele uma forma cultural. "Em outras palavras, ser uma mulher é tornar-se mulher; não é um vol.09, nº. 04, Rio de Janeiro, 2016.pp. 1955-1981 
problema de se submeter a um status ontológico fixo, mas envolve um conjunto de atos apropriativos e intencionais, a aquisição de uma pele, de um projeto, de assumir um certo estilo pessoal" (BUTLER, 1986, p. 36).

Portanto, tornar-se um gênero implica um processo de interpretação da realidade cultural carregada de sanções, tabus e prescrições recebidas de modo a reorganizá-las. "Em vez de um radical ato de criação, o gênero é um projeto tácito e contínuo para renovar a história cultural de alguém nos seus próprios termos" (BUTLER, 1986, p. 40). Simone de Beauvoir (2009, p. 69) complementa esse raciocínio ao ponderar que "é enquanto corpos submetidos a tabus, leis, que o sujeito toma consciência de si mesmo e se realiza: é em nome de certos valores que ele se valoriza. E, diga-se mais uma vez, não é a fisiologia que pode criar valores. Os dados biológicos revestem o que o existente lhes confere".

Então, gênero envolve um processo de construção de identidade, e não somente uma construção cultural, ou seja, o sujeito assume ou corporifica o gênero a partir da ressignificação de normas e discursos que incidem sobre os sujeitos corporais. E, para Butler, essa construção é influenciada pelos campos de poder e suas normas, não possuindo o sujeito possibilidade de redefini-los fora dessas relações institucionais (BUTLER, 1986, p.35).

Dessa forma, o processo de construção de identidade, além de resultar na escolha de um gênero prédeterminado, implica em mais limitações impostas ao sujeito em formação. Isso porque essa construção se dá também por atos corporais e modos de agir já esperados e fixados pela cultura (REIS, 2013, p.364).

Ao partir da constatação de que o efeito substantivo do gênero é performaticamente produzido e imposto pelas práticas reguladoras da lógica binária e heterossexual, Judith Butler defende a tese de que há possibilidade de subversão dessa identidade de gêneros. Isso seria possível a partir de dentro dos campos de poder que normatizam a sociedade. Então, por meio das possibilidades que surgem quando essa lógica se volta contra si mesma, como os casos de bissexualidade, homossexualidade, entre outros, seria possível estabelecer espaços para o sujeito interpretar e ressignificar essas normas sociais. Do mesmo modo, elucidar e atribuir novo significado ao seu próprio corpo, e, assim, construir sua identidade de gênero. "O corpo culturalmente construído será então libertado, não para seu passado natural, nem para seus prazeres originais, mas para um futuro aberto de possibilidades culturais" (BUTLER, 2015, p. 164).

Nesse sentido, Butler (2015, p. 254) considera que a tarefa crucial do feminismo não é estabelecer um ponto de vista fora das identidades construídas, mas, antes, a de situar as estratégias de repetição subversiva facultada por essas construções que constituem a identidade e, portanto, apresentar a possibilidade imanente de contestá-las. "Não basta inquirir como as mulheres podem se fazer representar mais plenamente na linguagem e na política. A crítica feminista também deve compreender como a categoria das mulheres, o sujeito do feminismo, é produzida e reprimida pelas mesmas estruturas de poder por intermédio das quais se busca a emancipação" (BUTLER, 2015, p. 20). A tarefa, portanto, consiste em reescrever as possibilidades que já existem, mas que vol.09, nº. 04, Rio de Janeiro, 2016.pp. 1955-1981 1966 
existem dentro de domínios culturais apontados como culturalmente ininteligíveis e impossíveis (BUTLER, 2015, p. 256).

A adoção dessa proposta subversiva é essencial para modificar as determinações culturais prescritas para o sexo e o gênero, a fim de alcançar uma identidade de gênero que permita a autorrealização do sujeito além de sua constituição biológica e de seu papel social.

Diante dessa complexidade, consoante será abordado na próxima seção, e uma vez que a divisão sexual do trabalho segue uma lógica binária e androcêntrica, é necessário revisar o Direito do Trabalho conforme uma perspectiva emancipatória do ser humano que atente para as reais potencialidades das mulheres.

\section{PROTEÇÃO DO TRABALHO DA MULHER: ANÁLISE A PARTIR DA TEORIA CRÍTICA DOS DIREITOS HUMANOS}

Diante de uma realidade fática que engendra as relações sociais de poder e a opressão exercida sobre as mulheres, a Constituição Federal Brasileira estabeleceu, no seu art. $1^{\circ}$, IV, como um dos fundamentos do Estado Democrático de Direito, a tutela dos valores sociais do trabalho, como expressão básica da proteção à dignidade humana e como forma de buscar o equilíbrio social e econômico.

Nesse sentido, igualmente o artigo 170 da Constituição da República fixa que a ordem econômica tem por fim assegurar a todos existência digna, conforme os ditames da justiça social, fundada na valorização do trabalho humano e na livre iniciativa. Acrescente-se que o art. 193 da Constituição Federal estabelece que a ordem social tem por base o primado do trabalho, objetivando o bem-estar e a justiça social.

No que tange à questão de gênero, o texto constitucional expressamente vedou a discriminação no mercado de trabalho por motivo de sexo, idade, cor ou estado civil (art. 70, XXX). Essa norma foi regulamentada pela Lei 9.029/1995, que veda qualquer atitude discriminatória em razão de gênero para ingresso e permanência no emprego, tipificando como crime as práticas discriminatórias (artigos $1^{\circ} \mathrm{e} 2^{\circ}$ ).

Um exemplo de prática discriminatória do trabalho da mulher, tipificada nesta lei, que tomou grande proporção na mídia nacional em 2013, foi o acórdão RR-755-28.2010.5.03.0143/MG, em face de uma empresa de call center ${ }^{19}$. Aqui se verificou que a gerente da empresa ré implementou um programa de controle gestacional no intuito de conciliar a gravidez das empregadas com o atendimento da demanda da empresa, prática expressamente vedada pelo art. $2^{\circ}$, II, 'b', da referida lei ${ }^{20}$. Neste caso, a prova documental demonstrou a existência de uma planilha elaborada pela gerência, estabelecendo uma fila de preferência para a atividade reprodutiva das

\footnotetext{
${ }^{19}$ TST, RR-755-28.2010.5.03.0143/MG, 7a T., Rel. Min. Ministro Luiz Philippe Vieira de Mello Filho, DJe 19/09/2014.

${ }^{20}$ Art. $2^{\circ}$ Constituem crime as seguintes práticas discriminatórias: II - a adoção de quaisquer medidas, de iniciativa do empregador, que configurem; b) promoção do controle de natalidade, assim não considerado o oferecimento de serviços e de aconselhamento ou planejamento familiar, realizados através de instituições públicas ou privadas, submetidas às normas do Sistema Único de Saúde vol.09, no. 04, Rio de Janeiro, 2016. pp. 1955-1981 1967
} 
trabalhadoras.

Verificada tal conduta ilícita, o magistrado de primeiro grau condenou a ré ao pagamento de indenização por dano moral no importe de $\mathrm{R} \$ 15.000,00$ (quinze mil reais). Interposto recurso ordinário pela ré, o Tribunal Regional da 3a Região acolheu o apelo para excluir a condenação ao pagamento de indenização por dano moral porque considerou não demonstrado "que a autora tenha sido exposta a situação humilhante ou constrangedora, ou mesmo sofrimento psicológico, pelo programa de gestação implementado pela empresa".

A 7a Turma do TST, por usa vez, reformou o acórdão regional, para reconhecer o dano moral e arbitrar indenização no importe de R \$50.000,00. Entenderam os ilustres Ministros que a comprovação da existência de um plano gestacional no âmbito da empresa "acarreta a conclusão de que todas as mulheres em idade reprodutiva envolvidas naquela planta empresarial foram ofendidas em sua dignidade (destacadamente na possibilidade de decidirem com autonomia a respeito de seus projetos de vidas, de felicidade e do seu corpo) e em sua intimidade, resultando discriminadas em razão sua condição feminina". Com fulcro nos artigos 5º I, da CF, 373-A e 391, parágrafo único, da CLT, o acórdão ressaltou ainda que o ordenamento jurídico pátrio "já voltou seu olhar para a especial vulnerabilidade das mulheres no mercado de trabalho, em razão das suas responsabilidades reprodutivas, razão por que prescreveu a ilicitude de qualquer conduta voltada ao controle do estado gravídico das trabalhadoras".

Ainda, no âmbito constitucional, o art. $7^{\circ}, \mathrm{XX}$, dispõe sobre a proteção especial da mulher no mercado de trabalho, mediante incentivos específicos. A Lei 9.799/1999 regulamentou essa norma, ao inserir na CLT regras sobre o acesso da mulher ao mercado de trabalho. Dentre essas alterações para eliminação da discriminação de gênero no trabalho, merecem destaque as seguintes condutas ilícitas previstas no art. 373-A: oferecer emprego com referência ao sexo (inciso I); recusar emprego, promoção ou motivar a dispensa do trabalho em razão de sexo ou estado de gravidez (inciso II); considerar o sexo como variável determinante para fins de remuneração, formação profissional e oportunidades de ascensão profissional (inciso III); exigir atestado ou exame, de qualquer natureza, para comprovação de esterilidade ou gravidez, na admissão ou permanência no emprego (inciso IV); proceder o empregador ou preposto a revistas íntimas nas empregadas ou funcionárias (inciso VI).

Ressalte-se, por fim, que a CLT dedicou um capítulo inteiro para o trabalho da mulher (Capítulo III, artigos 372 a 401). Consoante a perspectiva de gênero abordada na seção anterior, essas normas servem à lógica binária e heterossexual da construção da identidade de gênero, de acordo com a relação de poder estabelecida entre homens e mulheres. Isso porque não consideram as efetivas capacidades intelectual e física das mulheres para o desempenho das atividades laborais. 
Um exemplo notório dessa divisão sexual do trabalho, corroborada pelo ordenamento jurídico pátrio, é a previsão contida no art. 384 da CLT, que estabelece uma pausa de quinze minutos para as mulheres antes da realização de trabalho extraordinário ${ }^{21}$. A principal discussão gira em torno da recepção da referida norma em face da igualdade formal entre homens e mulheres prevista no art. $5^{\circ}$ da Constituição da República de 1988. Sobre este assunto, parte da doutrina afasta a incidência da referida pausa, pois considera a previsão inconstitucional em face da igualdade formal. Outros, embora reconheçam a recepção da referida norma pela nova ordem constitucional, julgam que não mais se justifica a discriminação positiva prevista no art. 384 da CLT entre o trabalho de homens e mulheres.

Ao analisarmos as teses expostas nas decisões judiciais, verifica-se como está enraizada na sociedade a atribuição de trabalho segundo o sexo e a desvalorização da atividade não produtiva, de cuidados domésticos e familiares, realizada essencialmente pelas mulheres. Nesse sentido, o Tribunal Superior do Trabalho pacificou o entendimento, segundo o qual a norma contida no art. 384 da CLT deve ser observada no trabalho da mulher, em face "do maior desgaste natural da mulher trabalhadora", principalmente em razão de sua atividade reprodutiva na sociedade, "o que justifica o tratamento diferenciado em termos de jornada de trabalho e período de descanso" (IIN-RR-1540/2005-046-12-00-5) ${ }^{22}$. A referida decisão também ressaltou a dupla jornada de trabalho a que estão submetidas as mulheres: "Por mais que se dividam as tarefas domésticas entre o casal, o peso maior da administração da casa e da educação dos filhos acaba recaindo sobre a mulher".

No que se refere ao âmbito internacional, há diversas regulamentações que versam sobre a tutela do trabalho da mulher, dentre as quais: a Convenção 100 da OIT sobre a Igualdade de Remuneração de Homens e Mulheres Trabalhadores por Trabalho de Igual Valor; a Convenção 103 sobre o Amparo à Maternidade e a Convenção 111 sobre a Discriminação em matéria de emprego e ocupação.

Na OEA (Organização dos Estados Americanos), o Brasil é parte na Convenção sobre a Eliminação de todas as Formas de Discriminação contra a Mulher, bem como do Pacto Internacional de Direitos Civis e Políticos e do Pacto Internacional de Direitos Econômicos, Sociais e Culturais, que incluem importantes proteções referentes aos direitos humanos da mulher.

Não obstante a importância das regulamentações nacionais e internacionais para a tutela do trabalho da mulher, estas não são nem suficientes e nem eficientes o bastante para a eliminação da discriminação de gênero no trabalho. A nosso ver, predominam legislações que, ou servem para confirmar a divisão sexual do trabalho, ou partem de um conceito equivocado do próprio trabalho, qual seja, como um direito formal, genérico, abstrato, segundo um padrão eurocêntrico de indivíduo.

\footnotetext{
${ }^{21}$ Art. 384. Em caso de prorrogação do horário normal, será obrigatório um descanso de 15 (quinze) minutos no mínimo, antes do início do período extraordinário do trabalho.

${ }^{22}$ IIN-RR - 1540/2005-046-12-00.5, Tribunal Pleno, Rel. Min. Ives Gandra Martins Filho, j. 17/11/2008, DJe13/02/2009. vol.09, nº. 04, Rio de Janeiro, 2016. pp. 1955-1981 
As mudanças necessárias para a eliminação da discriminação de gênero nas relações laborais pressupõem que o trabalho seja entendido como um direito humano, de acordo com a sua real capacidade de construção e emancipação do sujeito. Para tanto, adota-se a Teoria Critica dos Direitos Humanos, principalmente com base nos estudos desenvolvidos por Joaquín Herrera Flores, como marco de superação do dualismo entre universalismo e relativismo que marcam as discussões sobre os Direitos Humanos.

Consoante ensina Joaquín Herrera Flores, o termo "direitos humanos" é uma convenção adotada em 1948 no começo da Guerra Fria, convertendo-se no discurso ideológico hegemônico do novo processo de acumulação dos capitais simbólicos, sociais e culturais, da fase keynesiana do modo de produção capitalista. "A ideologia liberal - com seus componentes individualistas, abstratos e formalistas - se consolida como a visão natural e universal que se expressa clara e com matizes universalistas nas normas e nos textos que surgem na ordem institucional global das Nações Unidas" (FLORES, 2010, p. 87).

Ainda segundo o referido autor, nessa proposta ideológica liberal, o termo "humano" expressaria a essência abstrata e universal das pessoas. Já o termo "direito" serviria para apresentar os direitos humanos como um conteúdo puramente formal, estático e independente das ações humanas.

A efetividade dos direitos humanos requer a ruptura com essa visão liberal e eurocentrista, construída com o projeto da modernidade, conforme uma concepção positivista do Direito. Ou seja, conforme ressalta Flávia Piovesan (2006, p. 206), é necessário romper com o "paradigma do homem, ocidental, adulto, heterossexual e dono de um patrimônio para a visibilidade de novos sujeitos de direitos".

A referência cultural que atua no mundo, consoante esclarece David Sanchez Rubio, foi imposta por um modelo de ser humano masculino, branco, proprietário, maior de idade, europeu, cristão e meritocrata. As demais formas de expressões culturais são ignoradas. Nessa perspectiva, "os direitos humanos são como um traje que serviu e serve a um coletivo, porém é demasiadamente largo para que caibam todas as reivindicações, demandas de outros grupos, coletivos ou movimentos sociais" (RUBIO, 2014, p. 89).

Essa proposta universalizante tornou-se ainda mais evidente após as mudanças implementadas pelas chamadas políticas neoliberais. Conforme ensina Costas Douzinas (2011, p. 2), o atual capitalismo cosmopolita utiliza-se dos direitos humanos para difundir um falso humanismo-cosmopolitismo, ou seja, busca propagar uma visão de mundo comum, a fim de mascarar um falso humanismo do capitalismo e amenizar os efeitos colaterais da globalização. Nessa vertente, os direitos humanos perdem o objetivo de resistir à dominação e opressão, ao se transformarem em ideologia do capitalismo neoliberal ou na versão contemporânea da missão civilizatória (DOUZINAS, 2011, p.3).

Para a devida tutela dos direitos humanos, torna-se insuficiente tratar o indivíduo de forma genérica e abstrata, pois determinados sujeitos de direitos, ou determinadas violações de direitos, exigem uma resposta específica e diferenciada. Faz-se necessária a especificação do sujeito, a partir de suas peculiaridades e vol.09, no. 04, Rio de Janeiro, 2016.pp. 1955-1981 1970 
particularidades. Nesse sentido, Thereza Cristina Gosdal (2006, p. 311) afirma que "o grande desafio é que as diferenças sejam entendidas como particularidade, heterogeneidade do corpo e da afetividade, pluralidade de relações linguísticas e sociais; que sejam entendidas como diversidade, não como inferioridade".

O desejo de homogeneizar (ou normalizar) os indivíduos têm prevalecido sobre a pluralidade e diversidade. Qualquer diferença real entre as pessoas ou grupos somente entra em debate quando não provocar alguma discriminação diante da lei (igualdade formal). A diversidade é vista como mera dessemelhança que deve ser contornada por medidas que conduzam o diferente ao padrão universal de igualdade. "Se instaura a ideia de um sujeito generalizado tão tolhido dos contextos em que vive, que as situações de conflito desaparecem diante do consenso que supõe a igualdade formal e as situações de desigualdade desaparecem ante a aparência de justiça que revestem os procedimentos" (FLORES, 2010, p. 80).

Esse raciocínio é corroborado pela constatação de que os direitos individuais e políticos próprios de primeira geração, fruto da luta burguesa, e associados ao princípio de liberdade, possuem um grau de reflexão teórica e de eficiência superiores, por exemplo, aos direitos sociais.

A fim de superar essa postura eurocêntrica dos direitos humanos, é igualmente necessário romper com a visão de gerações ou dimensões de direitos, que "acaba por implantar uma cultura excessivamente anestesiada e circunscrita a uma única forma hegemônica de ser humano: a construída pelo Ocidente em sua trajetória e versão de modernidade liberal e burguesa" (RUBIO, 2014, p. 88). A definição de gerações de direitos humanos parte de uma afirmação histórica sobre sua origem que se absolutizou e retirou o caráter dinâmico desses direitos. É como se, uma vez reconhecidos, fossem sua expressão máxima para sempre.

Contudo, os direitos humanos não se reduzem a um único momento histórico e uma única dimensão jurídica, procedimental e formal. Conforme explica David Sánchez Rubio (2014, p. 101), não se trata de "um problema de geração, mas de direitos que surgem frente a problemas e racionalidades diversas que lutam por uma hegemonia previamente estabelecida pelo grupo social - a burguesia - que conseguiu estabelecer as regras do jogo como dar sentido ao conceito de direitos humanos".

Destarte, é preciso romper com a cultura formalista que entende o direito como simples técnica de regulação, construída e imposta por uma autoridade concreta. Todavia, também não se pode adotar a postura de direitos humanos mínimos, em uma concepção metafísica jusnaturalista, que acaba por descontextualizá-los e separá-los do conjunto de relações e ações humanas que os constroem e lhes confere significado.

Consoante explica Joaquín Herrera Flores (2010, p. 72), a fundamentação filosófica dos Direitos Humanos foi estabelecida conforme duas tendências: a universalidade dos direitos e sua condição inata à pessoa humana. As atrocidades cometidas durante o último século levaram a pensar que essa fundamentação metafísica fosse adequada, ou seja, que haveria essências humanas abstratas que não poderiam ser contrariadas, como se fossem uma espécie de reserva espiritual. 
Não é mais suficiente acreditar nessa concepção liberal dos direitos humanos, como direitos imutáveis e metafísicos, alheios aos espaços de ação humana onde ocorrem as lutas por satisfação de necessidades, emancipação e dignidade. Quando utilizamos o termo conceitual direitos humanos devemos considerar a complexidade da realidade humana. Esta é submetida a processos econômicos, sociais e culturais que fazem com que alguns tenham menos capacidade para satisfação de suas necessidades e construção de sua subjetividade/identidade, seja por razões de etnia, gênero, classe, cultura etc.

Caso contrário, iremos nos deparar com paradoxo apresentado por Costas Douzinas (2011, p. 11):

[...] as reivindicações e lutas pelos direitos humanos trazem à tona a exclusão, a dominação e a exploração, bem como os conflitos inevitáveis que permeiam a vida social e política. Mas ao mesmo tempo, elas escondem as raízes profundas do conflito de dominação ao enquadrar a luta e a resistência em termos de paliativos legais e individuais que, se bem-sucedidos, levam a pequenas melhorias de indivíduos e a um rearranjo insignificante do edifício social.

Feitas essas críticas, o presente trabalho adota o conceito de direitos humanos como processos sociais que permitem a satisfação de necessidades e a construção da subjetividade/identidade do indivíduo para uma vida digna. Entende-se os direitos humanos "como práticas sociais, expressões axiológica, normativa e institucional que em cada contexto abre e consolida espaços de luta por expressões múltiplas de dignidade humana" (RUBIO, 2014, p. 97).

Adota-se uma dimensão emancipatória, isto é, defende-se "que todo ser humano possa sexualmente, etnicamente, culturalmente, politicamente, economicamente, a partir de sua posição de gênero e socialmente, autoproduzir sua identidade e significar sua realidade como sujeito vivo e criador de realidades" (RUBIO, 2014, p. 14). Direitos humanos referem-se, portanto, a "processos de abertura e consolidação de espaços de lutas por diversas formas de entender a dignidade humana e como forma de acessar a bens que satisfazem necessidades humanas e que, em geral, são condicionadas por contextos materiais hegemônicos" (RUBIO, 2014, p. 48).

Os direitos humanos, em sua integralidade e dentro do universo normativo de resistência que aqui se defende, são mais que o conjunto de normas formais que os reconhecem e garantem em nível nacional ou internacional, pois compreendem os processos humanos que buscam construir e assegurar condições sociais, políticas, econômicas e culturais para os seres humanos perseverarem na luta pela satisfação de suas necessidades e aumentarem as potencialidades humanas. Diante dessas premissas, os direitos humanos podem ser definidos como:

O conjunto de processos sociais, econômicos, normativos, políticos e culturais que abrem e consolidam - desde o reconhecimento, a transferência de poder e a mediação jurídica espaços de lutas pela particular concepção da dignidade humana (FLORES, 2010, p. 98).

Concretamente, representam "o conjunto de práticas sociais, simbólicas, culturais e institucionais que têm reação contrária aos excessos de qualquer tipo de poder que impeçam os seres humanos de constituir-se como sujeitos" (RUBIO, 2014, p. 127). São nossas relações e práticas que nos permitem concluir se estamos construindo processos de reconhecimento, respeito e inclusão. 
Deve-se ressaltar, então, que os direitos humanos não se tratam de direitos construídos definitivamente, mas de processos, isto é, de lutas históricas e resultados de resistência contra a violência de diferentes manifestações do poder, consolidadas paulatinamente pela nova forma de produção e reprodução social no sistema capitalista.

Dentro dessa perspectiva emancipatória dos direitos humanos é que se insere o direito humano ao trabalho. Não se trata, simplesmente, de um direito abstrato e genérico, uma mera contraprestação pelo serviço prestado, pois o trabalho é uma das mais altas expressões da subjetividade humana. É também um grande alicerce de constituição do sujeito e de sua rede de significados.

Trata-se, a nosso ver, de direito humano ao trabalho, ou seja, processos de reconhecimento e respeito que permitam a satisfação de necessidades, a construção da subjetividade/identidade e o aumento das potencialidades humanas, de acordo com cada contexto social e cultural. Não haverá efetividade do direito humano ao trabalho se a construção do Direito do Trabalho e as formas de gestão do labor seguirem a lógica da divisão sexual do trabalho, sem considerar as reais potencialidades física e intelectual das mulheres. Do mesmo modo, devem-se enfrentar os empecilhos significativos impostos socialmente, como a maternidade, os cuidados familiares e domésticos.

Tendo em vista que o direito humano ao trabalho da mulher não é vivenciado dentro do universo normativo de resistência e autorrealização que defendemos neste artigo, será abordada na próxima seção a necessidade de adoção de políticas de discriminação positiva. Tal instrumento, entre outros, pode auxiliar na promoção da igualdade de oportunidades e corrigir as diferenças materiais de gênero.

\section{ANÁLISE EMPÍRICA DE DISCRIMINAÇÃO POSITIVA E DE GÊNERO NAS RELAÇÕES DE TRABALHO}

Segundo a pesquisa realizada para este trabalho, levando-se em consideração tanto os relatórios quanto as decisões judiciais, evidenciam-se que as mulheres continuam vítimas de discriminação em quase todos os aspectos da relação de emprego, incluindo o acesso, a remuneração, as promoções e as condições de trabalho.

Não obstante as iniciativas legislativas e políticas adotadas, essa análise demonstra que as diferenças de remuneração entre homens e mulheres, as dificuldades em conciliar trabalho com a vida familiar, a concentração desproporcional de mulheres no trabalho a tempo parcial, informal e precário, a discriminação com base na maternidade e a dificuldade de acesso, permanência e ascensão no trabalho, continuam a ser uma realidade concreta.

O tema é especialmente relevante, inclusive porque o combate à discriminação e melhora das condições de trabalho das mulheres é tema imprescindível para redução da pobreza e alcance de uma sociedade sustentável. 
Para corroborar tal entendimento cita-se um estudo realizado pela a Organização Internacional do Trabalho (OIT), no Brasil, entre 1992 e 2001, que analisou os efeitos da discriminação de gênero na pobreza, utilizando dados obtidos por meio do inquérito Nacional às Famílias. Verificou-se que, enfrentada a discriminação em base no gênero, a percentagem de pessoas em situação de pobreza tendia a diminuir em média 10\%. Os resultados eram ainda mais significativos nos segmentos mais vulneráveis da população, a exemplo dos membros agregados no contexto familiar onde mulheres negras (sem um contrato formal de emprego ou não sindicalizadas) são as responsáveis econômicas ${ }^{23}$.

É necessário ressaltar que, embora o posicionamento adotado neste trabalho seja no sentido de que devem ser eliminadas as barreiras de gênero, é essencial a análise da discriminação do trabalho feminino, bem como a busca por medidas que permitam eliminar essa situação. Diz-se isso, mesmo se tendo em mente que construção da identidade de gênero deve ocorrer conforme um processo dinâmico e contínuo, no qual o indivíduo é livre para significar e ressignificar o contexto no qual está inserido, uma vez que o gênero ainda é imposto como uma forma de dominação cultural para a submissão e limitação das mulheres.

A fim de eliminar a discriminação de gênero no trabalho defende-se que devem ser adotadas políticas de discriminação positiva, cujos fundamentos antropológico e axiológico estão identificados por Aldacy Rachid Coutinho (2000, p. 22) da seguinte forma: "a) compensação histórica de discriminações passadas; b) distintas oportunidades na concretude da via real, por fatores econômicos, sociais ou culturais".

Como é sabido, acrescenta-se a expressão "positiva" ao conceito de discriminação para enfatizar a distinção entre a discriminação voltada à exclusão, no sentido negativo, e a discriminação positiva voltada à realização e efetivação de direitos, mediante políticas de igualdade de oportunidades. "A discriminação positiva consiste na adoção de regras jurídicas que preveem um tratamento desigual para certos grupos minoritários desfavorecidos ou pessoas vítimas de segregação, com fito de garantir-lhes igualdade de oportunidades na estrutura social" (COUTINHO, 2000, p. 27).

Essa discriminação positiva parte de um pressuposto de igualdade de oportunidades, pautada por critérios de racionalidade e proporcionalidade para a diferença material. Isso porque medidas legislativas de igualdade meramente formal para o combate à segregação no mercado de trabalho têm eficácia limitada às discriminações diretas, não abrangendo "tratamentos desiguais tomados a partir de estereótipos e segregação cultural que individualizam o sujeito para além de suas características pessoais, habilidades e capacidade" (COUTINHO, p. 2000, p. 23).

\footnotetext{
23 Relatório da OIT sobre igualdade no trabalho, 2011, p.27, disponível em http://www.oitbrasil.org.br/sites/default/files/topic/discrimination/pub/igualdade\%20no\%20trabalho_relatorio\%202011_707 .pdf vol.09, no. 04, Rio de Janeiro, 2016.pp. 1955-1981 
É preciso ressaltar que toda política de discriminação positiva deve considerar as efetivas capacidades dos sujeitos envolvidos e não meramente sua condição de inferioridade. Ou seja, o sujeito deve sentir-se capaz de alcançar a colocação no mercado de trabalho desejada independente da diferença de gênero.

Nesse sentido, as políticas públicas para o combate da discriminação de gênero no mercado de trabalho devem promover a igualdade de oportunidades e corrigir as diferenças materiais de gênero, atribuindo-lhes diferentes tratamentos jurídicos, de forma temporária. Para tanto, as mulheres devem ser vistas conforme as especificidades de sua condição social, o que thes assegura um tratamento especial. "O direito à diferença implica o direito ao reconhecimento de identidades próprias, o que propicia a incorporação da perspectiva de gênero, isto é, repensar, revisitar e reconceptualizar os direitos humanos a partir da relação entre gêneros, como um tema transversal" (PIOVESAN, 2006, p. 206).

A estruturação de sistemas de proteção social e políticas públicas capazes de contribuir efetivamente à superação das desigualdades de gênero pressupõe superar a noção de mulher como força de trabalho secundária. Essa inserção secundária, eventual e instável é vista nas organizações como custos indiretos, associados à maternidade e ao cuidado infantil, absenteísmo, alta taxa de rotatividade, baixo grau de compromisso com a empresa, impossibilidade de realizar horas extras e trabalho noturno, de viajar, entre outros (ABRAMO, 2010, p. 23).

O alcance da autonomia econômica das mulheres está diretamente relacionado à melhoria de sua inserção no mercado de trabalho e de seus rendimentos, bem como pela distribuição mais equitativa dos afazeres domésticos e das atividades de cuidado. Os indicadores reunidos no Relatório Anual Socioeconômico da Mulher (RASEAM, 2014) mostram que permanecem muitos obstáculos para o alcance da plena autonomia econômica das mulheres brasileiras. Em 2012, a taxa de atividade das mulheres de 16 a 59 anos era de 64,2\%, bastante inferior à dos homens (86,2\%). Esses indicadores são ainda mais discrepantes ao considerarmos a taxa de atividade das mulheres negras $(62,2 \%)$ em relação aos homens brancos $(86,5 \%)^{24}$.

Outro fator relevante a destacar, consiste na chamada dupla jornada, uma vez que alia o acesso das mulheres a determinados empregos limitados com base no seu papel reprodutivo e por continuarem a assumir a principal responsabilidade pelos cuidados domésticos e familiares. De acordo com o relatório do Observatório Brasil de Igualdade de Gênero e Secretaria de Políticas para Mulheres²5 (2015, p. 20), em 2012, a jornada total das mulheres, somando-se o tempo dedicado ao trabalho principal (mais de 35 horas semanais) e aos afazeres domésticos (quase 21 horas semanais), era sempre superior à jornada total dos homens (quase 42 horas dedicadas ao trabalho principal e 10 horas aos afazeres domésticos).

\footnotetext{
${ }^{24}$ Relatório disponível em http://www.spm.gov.br/central-de-conteudos/publicacoes/publicacoes/2015/livroraseam_completo.pdf

${ }^{25}$ Ibidem
} 
Esses dados evidenciam que a entrada das mulheres de forma mais expressiva no mercado de trabalho não foi acompanhada por um aumento equivalente da participação dos homens na distribuição das responsabilidades domésticas e familiares, ou por políticas públicas e mudanças na organização produtiva que pudessem diminuir essa tensão.

Tal sobrecarga dificulta seu acesso e permanência no trabalho, bem como a sua ascensão profissional. Por isso, a disponibilidade de vagas em creches é um importante indicador da autonomia econômica das mulheres. De acordo com o Relatório Socioeconômico da Mulher, em 2012, somente 20,3\% das mulheres com filhas/os de 0 a 3 anos tinham acesso a creches. Entre as mulheres com todos os filhos/as de 0 a 3 anos na creche, $72,9 \%$ estavam ocupadas, enquanto somente $42,6 \%$ daquelas sem nenhum filho/a na creche tinham ocupação ${ }^{26}$ (2015, p. 16).

Essa postura, do trabalho da mulher como secundário, em razão da responsabilidade pelos cuidados domésticos e familiares, mostra-se equivocada, uma vez que em nosso país inúmeras famílias dependem da renda do trabalho da mulher para a sobrevivência. Em 2010, de acordo com os dados do último Censo Demográfico divulgados pelo IBGE, 37,3\% das 50,0 milhões de famílias (únicas e conviventes principais) que residiam em domicílios particulares, tinham a mulher como responsável. Além disso, a contribuição delas, no rendimento familiar, era de 40,9\% em média. Observe-se, ainda, que o grau de responsabilidade pela renda de sua família daquelas mulheres com filho e sem cônjuge foi equivalente a $87,4 \%$ da renda familiar ${ }^{27}$.

A relevância do rendimento feminino é maior nas regiões menos desenvolvidas do país e nos casos em que o responsável é afrodescendente. Enquanto no Nordeste o indicador chegou a 46,8\%, no Centro-Oeste foi o mais baixo entre as regiões, de 37,8\%. Para as mulheres residentes em áreas rurais, a contribuição monetária no rendimento familiar total foi ligeiramente maior (42,4\%). Nas famílias em que o responsável era negro ou pardo o indicador chegou a 42,0\%, em famílias com responsável branco a contribuição das mulheres foi 39,7\%. Nas famílias formadas por casais, a média da participação do rendimento feminino foi de 33,5\% quando não havia filho e de $31,7 \%$ quando presente este, enquanto nas famílias monoparentais - responsável sem cônjuge e com filho(s) - o indicador atingiu $70,8 \%{ }^{28}$.

Cabe ainda, ao lado dessas questões, frisar a pouca efetividade nas demandas judiciais reparadoras no tema da violência real e simbólica de gênero. Corrobora essa conclusão a análise dos fundamentos expressos nas decisões judiciais que envolvem casos de assédio sexual proferidas no âmbito de jurisdição do Tribunal Regional do Trabalho da 9a Região (Paraná).

\footnotetext{
${ }^{26}$ Ibidem

${ }^{27}$ Dados disponíveis em http://biblioteca.ibge.gov.br/visualizacao/livros/liv88941.pdf

${ }^{28}$ Ibidem
} vol.09, no. 04, Rio de Janeiro, 2016. pp. 1955-1981 
Os fundamentos consignados nas decisões analisadas demonstram que um dos grandes empecilhos para o reconhecimento do assédio sexual é a exigência de prova inequívoca do ato ilícito. Desse modo, impõem-se às vítimas a produção de prova dita diabólica. Tal exigência é um óbice para a eliminação dessa espécie de agressão à mulher, pois o assédio sexual manifesta-se, geralmente, de forma velada no ambiente de trabalho.

Cita-se como exemplo o acórdão proferido no RO-01758-2012-015-09-00-7/TRT9 ${ }^{29}$. No referido feito, a autora alegou que sofreu assédio sexual por parte de seu líder, caracterizado por convites eróticos, expressões obscenas, brincadeiras grosseiras com conotação sexual, frases vulgares sobre seu corpo e atos molestadores. Outras empregadas já haviam denunciado o assediador, inclusive, junto à delegacia e ao Ministério Público do Trabalho. A testemunha indicada pela parte autora "afirmou que ficou sabendo, através de boatos, que o referido líder 'dava em cima' da reclamante, sendo que já havia percebido que desde que iniciou o labor no setor, a reclamante teve queda de produtividade e ia chorar no banheiro". A conclusão da prova pericial foi no sentido de que a autora estava "acometida por transtorno depressivo grave e com sequelas emocionais decorrentes do assédio sexual e moral sofridos no trabalho".

Mesmo diante desse contexto probatório, o ilustre Relator do acórdão concluiu que "da prova oral produzida, não se extrai a ocorrência do alegado assédio sexual ou moral. A única testemunha ouvida nos autos não presenciou os fatos narrados pela reclamante, somente possuindo conhecimento dos mesmos através de boatos". Ainda, ressaltou que "embora o laudo pericial tenha sido conclusivo pela existência de nexo de causalidade da patologia da reclamante com o assédio sexual e moral sofrido na reclamada, verifica-se que este foi baseado tão somente nos atestados médicos trazidos pela reclamante e pelo relato desta". ${ }^{30}$

Outrossim, verifica-se que muitos juízes se prendem ao tipo penal para a caracterização do assédio sexual no processo trabalhista, ou seja, somente reconhecem o assédio sexual se praticado por superior hierárquico, ignorando o fato de que o temor de perder o emprego ou de ser prejudicada no trabalho pode ser ocasionado inclusive por pares no trabalho. Nesse sentido, são os fundamentos expressos no acórdão proferido pela no RO00509-2012-678-09-00-6/TRT9 ${ }^{31}$ (destaques acrescidos):

[...] Todavia, o quadro fático comprovado nos autos revela a inexistência do uso do poder hierárquico na conduta do assediador, mormente porque ocupava provisoriamente o posto do auxiliar de supervisor, a cujo titular a Autora também não estava subordinada

\footnotetext{
${ }^{29}$ TRT9, RO-01758-2012-015-09-00-7, 3a T., Rel. Des. Neide Alves dos Santos, DJe 10/12/2013.

${ }^{30}$ Cita-se outra decisão que reproduz os valores que aqui se critica, autos RTOrd-11739-2012-001-09-00-6/TRT9, que, em primeira instância, rejeitou os pedidos de indenização por dano moral e assédio sexual por entender que "a circunstância de a reclamante sentir-se incomodada com as investidas de seu chefe é insuficiente para caracterizar o dano moral alegado. (...)Ainda que "X" tenha ultrapassado o limite da razoabilidade na festa de final de ano, é imperioso considerar que isto correspondeu a fato isolado dentro do contexto geral de suas investidas e que a reclamante foi à confraternização porque quis, mesmo sabendo que ele estaria presente". A sentença foi reformada pela $1^{\text {a }}$ Turma do TRT9, que, embora não reconheceu o assédio sexual, deferiu indenização por dano moral (RO- 11739-2012-001-09-00-6, 1ª T., Rel. Des. Edmilson Antonio De Lima, DJe 05/07/2013).

${ }^{31}$ TRT9, RO-00509-2012-678-09-00-6, 4a T., Rel. Des. Márcia Domingues, DJe 13/07/2012.
} 
hierarquicamente, sendo este responsável apenas pelas instruções técnicas do trabalho que deveria ser executado.

Nesse passo é que não se vislumbra condição hipossuficiente ou intimidante da Autora em face da conduta inadequada do assediador, tanto assim que a ocorrência foi prontamente levada à chefia e tão logo por ela apurada. $\underline{\mathrm{O} \text { assediador, portanto, não tinha meios de obter }}$ vantagem ou de intimidar a Autora em decorrência do seu posto funcional, já que não exercia nenhum poder hierárquico sobre a vítima que pudesse manipular em seu benefício para lograr êxito em suas investidas.

Diante do cenário acima descrito, parece-nos nítido o tratamento discriminatório conferido ao trabalho da mulher, inclusive quando tratado o tema de reparação do dano causado pelo assédio sexual, conforme verificado.

\section{CONSIDERAÇÕES FINAIS}

Consoante acima verificado, a discriminação de gênero ainda é uma realidade bastante presente nas relações laborais das brasileiras. Não obstante alguns avanços obtidos na última década, por intermédio de políticas públicas protetivas do trabalho da mulher, almeja-se uma mudança mais estrutural e efetiva na temática. Busca-se, além da superação da divisão sexual do trabalho, a própria construção da identidade de gênero e a essencial compreensão do trabalho como um Direito Humano, conforme uma dimensão emancipatória.

Diante do exposto aqui, a construção da identidade de gênero não pode ser ingenuamente entendida como algo natural da espécie humana. Ao contrário, o gênero consiste em um aspecto da identidade gradualmente adquirido, pois envolve um processo contínuo e dinâmico de construção da identidade por meio da interpretação e ressignificação das normas e possibilidades abertas culturalmente ao sujeito para assumir um corpo, um estilo, um modo de vida.

Assim, ser de um determinado sexo não é uma causa necessária para se tornar um determinado gênero. Contudo, em vez desse universo de possibilidades para o sujeito ressignificar sua história, em nossa sociedade, o gênero é performativamente construído, conforme uma lógica binária e heterossexual, por meio de normas que mascaram o conteúdo opressor dessa racionalidade androcêntrica.

Tendo em vista que a construção da identidade de gênero, na nossa sociedade, é entendida como um processo natural e como uma imposição cultural, pode-se afirmar que a discriminação de gênero tem origem na própria construção social das identidades. $O$ discurso da naturalidade no tema faz com que as atividades femininas sejam entendidas como derivações biológicas e não como formulações socioculturais, historicamente forjadas. Nesse sentido, a discriminação do trabalho da mulher é consequência direta da relação de poder opressora estabelecida entre homens e mulheres, que relega o trabalho da mulher a atividades improdutivas ou socialmente desvalorizadas. 
Embora exista uma significativa previsão normativa no âmbito nacional e internacional, estas não se mostram suficientemente eficazes, além disso, muitas leis apenas servem ao propósito de confirmar a divisão sexual do trabalho, sem considerar as efetivas potencialidades intelectual e física das mulheres para o desempenho das atividades laborais.

Acrescente-se que as previsões normativas partem de um conceito de Direito do Trabalho que nos parece equivocado, desconectados das realidades locais e o papel do labor na construção da subjetividade/identidade e no desenvolvimento das potencialidades humanas. Ou seja, estabelecem um direito humano ao trabalho, abstrato, genérico, formal, quase metafísico, conforme um padrão eurocêntrico e capitalista de sujeito.

A efetividade dos direitos humanos requer a ruptura com essa visão liberal e eurocentrista, construída com o projeto da modernidade, conforme uma concepção positivista do Direito. Para a devida tutela dos Direitos Humanos, torna-se insuficiente tratar o indivíduo de forma genérica e abstrata, pois determinados sujeitos de direitos, ou determinadas violações de direitos, exigem uma resposta específica e diferenciada.

Por isso, compreende-se Direitos Humanos como processos sociais que permitem a satisfação de necessidades e a construção da subjetividade/identidade do indivíduo para uma vida digna, conforme determinados marcos teóricos. Fala-se, então, de direitos humanos como dimensão emancipatória, isto é, processos de abertura e consolidação de espaços de lutas por diversas formas de entender a dignidade humana e como forma de acessar a bens que satisfazem necessidades do ser.

Dentro dessa perspectiva emancipatória é que se insere o direito humano ao trabalho da mulher. Não se trata de um direito abstrato e genérico, um simples meio de subsistência, pois o trabalho é uma das mais altas expressões da subjetividade humana. É também um grande alicerce de constituição do sujeito e de sua rede de significados.

Defende-se, portanto, processos de reconhecimento e respeito ao trabalho feminino que permitam a satisfação de necessidades, construção da subjetividade/identidade e o aumento das potencialidades humanas, de acordo com cada contexto social e cultural, na busca da substancial concretização da igualdade e a eliminação de obstáculos da discriminação de gênero.

\section{A CRITICAL ANALYSIS ABOUT THE EFFECTIVENESS OF HUMAN RIGHT TO WORK: AN IMPASSE IN GENDER DISCRIMINATION}

\section{Abstract}

Parting from a qualitative analysis of empirical data available in the Gender's Reports codeveloped by the Geographical and Statistical Brazilian Institute (IBGE), the Politics for Women Public Office (SMP) and the vol.09, nº. 04, Rio de Janeiro, 2016.pp. 1955-1981 1979 
International Labor Organization (ILO), this paper aims to demonstrate that the gender discrimination still happens to women in the work relations, which may be explained by the difficulties linked to their job insertion, permanence and development. The results obtained, based on the analysis of gender reports and literature review, show that this scenario is caused by the social construction of gender identity, according to the reiteration of rules that regulate and produce the various corporeal beings, that follow a heterosexual and androcentric logic. This process of social identity formation confirms the sexual labor division, which engenders relations of exploration, domination and oppression in the women's productive and reproductive work. Finally, based on a critical reading of the internal rules and of the international treaties that regulates women's work, and on judicial decisions involving their work, this study suggests that is necessary to adopt politics of positive discrimination and to establish the Human Right to work concept as an emancipatory dimension, so that equal opportunities can be promoted and gender materials differences can be corrected. This research used qualitative, exploratory and bibliographic instruments.

Keywords: Gender. Human Rights. Discrimination. Sexual labor division. Women work.

\section{REFERÊNCIAS}

ABRAMO, Laís. In Igualdade de gênero e raça no trabalho: avanços e desafios. Brasília: OIT, 2010, p.17-47.

BEAUVOIR, Simone (1908-1986). O Segundo Sexo. 2. ed. Rio de Janeiro: Nova Fronteira, 2009.

BUTLER, Judith. Sex and Gender in Simone de Beauvoir's Second Sex.In Yale French Studies. N. 72, Simone de Beauvoir: Witnessto a Century. (1986), pp. 35-49.

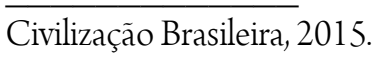

Problemas de gênero: feminismo e subversão da identidade. $8^{a}$ ed. Rio de Janeiro:

COUTINHO, Aldacy Rachid. Relações de Gênero no Mercado de Trabalho: uma abordagem da discriminação positiva e inversa. In: Revista da Faculdade de Direito da UFPR V. 34. Curitiba: 2000, p.13-34.

COZERO, Paula Talita. O sexo da precarização: transformações nas relações trabalhistas e perpetuação da divisão sexual do trabalho. In: Trabalho e direito: estudos contra a discriminação e patriarcalismo. RAMOS FILHO, Wilson; GOSDAL, Thereza Christina; WANDELLI, Leonardo Vieira (Org.). Bauru: Canal 6, 2013.

DOUZINAS, Costas. Os paradoxos dos direitos humanos. In: Pensar os Direitos Humanos: desafios à educação nas sociedades democráticas. v. 1. n. 1. UFG: 2011. Disponível em: http://www.cienciassociais.ufg.br/up/106/o/ConferenciaAberturax.pdf?1350490879

FLORES, Joaquín Herrera. Los Derechos Humanos en El Contexto de laGlobalización: TresPrecisionesConceptuales. In: Direitos humanos e globalização: fundamentos e possibilidades desde a teoria crítica / RÚBIO, David Sánchez; FLORES, Joaquín Herrera; CARVALHO, Salode (org.).2a ed. Porto Alegre: EDIPUCRS, 2010, p. 72-109.

FREIRE, Nilcéa. In: Igualdade de gênero e raça no trabalho: avanços e desafios. Brasília: OIT, 2010.

GOSDAL, Thereza Cristina. Diferenças de gênero e discriminação no trabalho. In: A igualdade dos gêneros nas relações de trabalho. PENIDO, Laís de Oliveira (coord.); Brasília: Escola Superior do Ministério Público da 
União, 2006, p. 305-318.

HARVEY, David. Condição Pós-Moderna: uma pesquisa sobre as origens a mudança cultural. 24. ed.São Paulo: Edições Loyola, 2013.

MARQUES, Lílian Arruda; SANCHES, Solange. Desigualdades de Gênero e Raça no Mercado de Trabalho: tendências recentes. In: Igualdade de gênero e raça no trabalho: avanços e desafios. Brasília: OIT, 2010, p.50-79.

MATOS, Marliseet al. Acesso ao Direito e à Justiça Brasileiros na Perspectiva de Gênero/ Sexualidade, Raça/Etnia: Entre o Estado e a Comunidade. Belo Horizonte: Faculdade de Filosofia e Ciências Humanas, 2010/2011.

MORAES, Eunice Léa de. A Política de Promoção da Igualdade de Gênero e a Relação com o Trabalho. In: Igualdade de gênero e raça no trabalho: avanços e desafios. Brasília: OIT, 2010, p. 83-100.

PIOVESAN, Flávia. Direitos humanos das mulheres no Brasil: desafios e perspectivas. In: A igualdade dos gêneros nas relações de trabalho. PENIDO, Laís de Oliveira (Coord.); Brasília: Escola Superior do Ministério Público da União, 2006, p.205-212.

RAMOS FILHO, Wilson. Direito Capitalista do Trabalho: história, mitos e perspectivas no Brasil. São Paulo: LTr, 2012.

REIS, Daniele Fernandes. Ideias subversivas de gênero em Beauvoir e Butler. In: Sapere Aude - v.4. n.7. Belo Horizonte: $\quad 1^{\circ} \quad$ sem. 2013, p.360-367. Disponível em: http://periodicos.pucminas.br/index.php/SapereAude/article/view/4880

RUBIO, David Sánchez. Encantos e Desencantos dos Direitos Humanos: de emancipações, libertações e dominações. LIXA, Ivone Fernandes Morcilho; HENKIN, Helena (trad.). Porto Alegre: Livraria do Advogado, 2014.

SAFFIOTI, Heleieth. Rearticulando gênero e classe social. In: Uma questão de gênero. COSTA, Albertina de Oliveira; BRUSCHINI, Cristina (Org.). São Paulo: Fundação Carlos Chagas, 1992.

Trabalho enviado em 26 de março de 2016.

Aceito em 16 de julho de 2016. 